\title{
Neurotoxin-Sensitive Sodium Channels in Neurons Developing In Vivo and In Vitro
}

\author{
François Couraud, ${ }^{\star}$ Nicole Martin-Moutot, ${ }^{\star}$ Annette Koulakoff, $\dagger$ and Yoheved Berwald-Netter $\dagger$ \\ *Laboratoire de Biochimie, I.N.S.E.R.M., U.172, Faculté de Médecine Nord, 13326 Marseille Cédex 15, \\ †Biochimie Cellulaire, Collège de France, 75231 Paris Cédex 05, France
}

Fetal mouse brain cells were investigated by ${ }^{22} \mathrm{Na}^{+}$flux assays with the aim to determine the ontogenetic time course of appearance of functional voltage-sensitive sodium channels. Their pharmacological properties were assessed by measurement of the response to known neurotoxins, acting at site 1, 2, or 3 of the $\mathrm{Na}^{+}$channel. Brain cell suspensions, prepared at 11-19 d of prenatal development in vivo, and fetal brain neurons in culture were explored. In vivo neurotoxin-sensitive $\mathrm{Na}^{+}$influx becomes detectable at $12 \mathrm{~d}$ of gestation, in concordance with the time of appearance of saturable binding sites for $\alpha$-scorpion toxin $(\alpha-\mathrm{ScTx})$ and saxitoxin. Progression in fetal age or in time in vitro is accompanied by an increase in the initial rate and in the amplitude of $\mathrm{Na}^{+}$uptake stimulated by batrachotoxin or veratridine. The general pharmacological properties of developing $\mathrm{Na}^{+}$channels are very similar to the known properties of voltage-dependent $\mathrm{Na}^{+}$channels in adult nerve: (1) Batrachotoxin acts as a full channel agonist and veratridine as a partial agonist. Their respective apparent affinities are increased in presence of $\alpha$-ScTx, in agreement with the known positive cooperativity of toxins acting at sites 2 and 3 of the $\mathrm{Na}^{+}$channel. (2) $\alpha$-ScTx alone induces a small increase in $\mathrm{Na}^{+}$permeability; its effect is greatly amplified in the presence of batrachotoxin or veratridine. The apparent affinity of $\alpha$-ScTx is reduced by cell depolarization. (3) Tetrodotoxin and saxitoxin block the increase in $\mathrm{Na}^{+}$permeability induced by batrachotoxin, veratridine, and $\alpha$-ScTx. (4) The $K_{0.5}$ of $\alpha$-ScTx, tetrodotoxin, and saxitoxin (determined in $\mathrm{Na}^{+}$flux assays) agrees well with the corresponding dissociation constant $\left(K_{p}\right)$ values. (5) The rate of $\mathrm{Na}^{+}$uptake, measured in neuronal cultures, is $5 \times 10^{6} \mathrm{Na}^{+}$ions/ $\mathrm{min} / \mathrm{saxitoxin}$ binding site, which is quite close to the values reported for ion transport through the voltage-dependent $\mathbf{N a}^{+}$ channel in other excitable cell systems. Taken together these results indicate that normal functional $\mathrm{Na}^{+}$channels are present in fetal brain neurons at a very early stage of their phenotypic maturation. The only qualitative change detected during neuronal maturation is in the apparent affinity of batrachotoxin and of veratridine, which, in cultures of neuronal cells engaged in neurite formation, is one order of magnitude lower than in cells with well-developed neuritic network.

Voltage-sensitive sodium channels are essential for the generation and propagation of action potentials along the membrane

\footnotetext{
Received Nov. 15, 1984; revised July 30, 1985; accepted July 30, 1985.

This work was supported in part by the C.N.R.S. (UA 040 553), I.N.S.E.R.M. (CRE 83 6003), M.R.T. (Action Dynamique du Neurone), and D.R.E.T. We are grateful to Dr. J. Daly for the generous gift of batrachotoxin and to Mrs. Paule Deprez and Mrs. Edwige Houzet for expert assistance in the preparation of cell suspensions and cultures.

Correspondence should be addressed to Dr. François Couraud, Laboratoire de Biochimie, I.N.S.E.R.M., U.172, Faculté de Médecine Nord, 13326 Marseille Cedex 15, France.

Copyright (C) 1986 Society for Neuroscience $0270-6474 / 86 / 010192-07 \$ 02.00 / 0$
}

of neuronal cells. Their presence and activity can be detected and studied using specific neurotoxins. The latter have been classified into four groups according to their binding and pharmacological properties, leading to the definition of four distinct receptor sites on the voltage-dependent $\mathrm{Na}^{+}$channel (Catterall, 1980; Couraud et al., 1982): Site 1, related to the selectivity filter of the channel, recognizes tetrodotoxin (TTX) and saxitoxin; site 2, at which the liposoluble toxins batrachotoxin (BTX) and veratridine bind and induce a persistent activation of sodium permeability; site 3 recognizes polypeptide $\alpha$-scorpion toxins and sea anemone toxins, which cause a slowing of channel inactivation; site 4 , the occupancy of which by $\beta$-scorpion toxins provokes the appearance of an abnormal sodium permeability occurring on membrane repolarization. Sodium channels were characterized by measurements of the toxins' binding properties or the modifications of the inward ${ }^{22} \mathrm{Na}^{+}$flux (Agnew, 1984; Catterall, 1984; Catterall et al., 1981; Jover et al., 1980a, b; Lazdunski and Renaud, 1982; Ritchie et al., 1976; Strichartz et al., 1983). These methods can be exploited to follow the emergence and study the properties of functional sodium channels during neuronal development.

Previously we have shown that the binding sites for $\alpha$-scorpion toxin and for saxitoxin appear in fetal mouse brain early in development (on the 12 th $\mathrm{d}$ of gestation) and increase in number during nervous system maturation (Berwald-Netter et al., 1981; Beaudoin et al., in press). A similar evolution was observed in fetal brain neurons developing in culture. Here we report on studies of neurotoxin-modulated sodium permeability in cells of developing mouse brain. Freshly dissociated braincell suspensions were used to follow the evolution of sodium channels during in vivo ontogenesis, while in vitro development was monitored in cultures of neuronal cells derived from fetal mouse brains at $15 \mathrm{~d}$ of gestation.

\section{Materials and Methods}

\section{Toxins and chemicals}

The $\alpha$-scorpion toxin ( $\alpha$-ScTx) was purified from the venom of the scorpion Androctonus australis Hector (AaHII) according to Miranda et al. (1970); BTX was a generous gift from Dr. John Daly (Laboratory of Bioorganic Chemistry, National Institute of Health); saxitoxin was obtained from the National Institute of Health; TTX was purchased from Boehringer Mannheim; veratridine from Aldrich; ouabain, HEPES, and bovine serum albumin were from Sigma. Components of the culture media were from GIBCO and ${ }^{22} \mathrm{Na}^{+}(100-1000 \mathrm{mCi} / \mathrm{mg} \mathrm{Na})$ from Amersham International.

\section{Cell suspensions and cultures}

Single cell suspensions were prepared from brains of fetal mice by mechanical dissociation, and cultures of neuronal cells were set up from brains at $15 \mathrm{~d}$ of gestation $\left(\mathrm{E}_{15}\right)$, as previously described (Berwald-Netter et al., 1981). Plastic culture plates (35 mm, from Corning or Nunc) or multiwell plates (Linbro, FB-12-TC) were used, coated with rat tail 

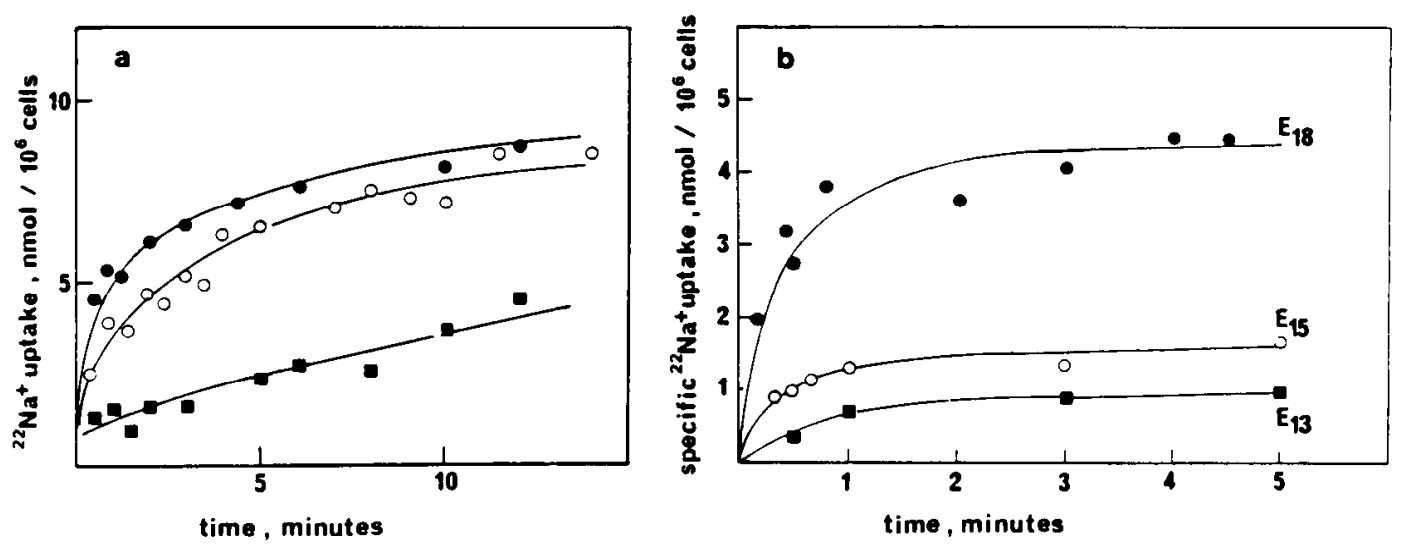

Figure 1. Time course of neurotoxin-stimulated ${ }^{22} \mathrm{Na}^{+}$uptake into fetal mouse brain cells. $a$, Brain cell suspensions were from $\mathrm{E}_{18}$ fetuses. After a 20 min preincubation without $(\square, 0)$ or with $(\Theta) \alpha$-ScTx, cells were incubated at $37^{\circ} \mathrm{C}$ for the indicated times in medium (see Methods) containing

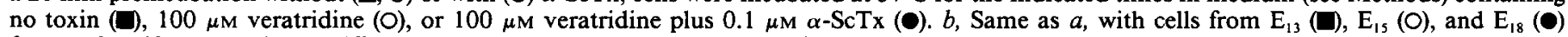
fetuses. Specific uptake is the difference between uptake in the presence of $100 \mu \mathrm{M}$ veratridine plus $0.1 \mu \mathrm{M} \alpha$-ScTx and uptake without any toxin (nonspecific). The calculated initial rates of uptake $\left(v_{i}\right)$ were, respectively, $0.65\left(\mathrm{E}_{13}\right), 1.45\left(\mathrm{E}_{15}\right)$, and $3.64\left(\mathrm{E}_{18}\right) \mathrm{nmol} / \mathrm{min} / 10^{6} \mathrm{cells}$.

collagen and polyornithine ( $2 \mu \mathrm{g} / \mathrm{ml}$; Sigma) to facilitate cell adhesion. Cells were seeded at $2.5 \times 10^{5}$ viable cells $/ \mathrm{cm}^{2}$. The culture medium was MEM-Earle (from Seromed, Berlin) containing $2.2 \mathrm{gm} / \mathrm{liter}$ $\mathrm{NaHCO}_{3}$ and supplemented with L-glutamine $0.3 \mathrm{mg} / \mathrm{ml}$, penicillin 50 $\mathrm{U} / \mathrm{ml}$, gentamycin $12.5 \mu \mathrm{g} / \mathrm{ml}$, glucose at a final concentration of $6 \mathrm{gm} /$ liter, insulin $5 \mu \mathrm{g} / \mathrm{ml}$, pyruvate $110 \mathrm{mg} / \mathrm{ml}$, fetal calf serum $2.5 \%$, and horse serum $2.5 \%$. Cell division was blocked by either cytosine arabinoside at $1 \mu \mathrm{g} / \mathrm{ml}$ or 5 -fluorodeoxyuridine at $2 \times 10^{-5} \mathrm{M}$, added at $\approx 48$ $\mathrm{hr}$ in vitro and maintained thereafter. Partial medium change was made once a week. The cultures were composed predominantly of neuronal cells identified by surface receptors for tetanus toxin (Koulakoff et al., 1983); they contained no oligodendrocytes identifiable by antibodies to galactocerebroside; in the older cultures, $\approx 5 \%$ of cells were astrocytes identified by antibodies to GFAP.

\section{Measurements of ${ }^{22} \mathrm{Na}^{+}$influx in brain cell suspensions}

Dissociated brain cells were collected by centrifugation and resuspended in $\mathrm{Na}^{+}$-free medium (SFM) containing $140 \mathrm{mM}$ choline chloride, 5.4 $\mathrm{mm} \mathrm{KCl}, 1.8 \mathrm{~mm} \mathrm{CaCl}_{2}, 0.8 \mathrm{~mm} \mathrm{MgSO}_{4}, 10 \mathrm{~mm}_{\text {glucose, }} 25 \mathrm{~mm}$ HEPES, and $1 \mathrm{mg} / \mathrm{ml} \mathrm{BSA}$. Tris-base was used to adjust the $\mathrm{pH}$ to 7.3 . The cells were washed once in this medium to eliminate extracellular sodium. Aliquots $(0.05 \mathrm{ml})$ of the cell suspension (1-2 $\times 10^{6}$ cells/assay) were preincubated for $20 \mathrm{~min}$ at $37^{\circ} \mathrm{C}$ in the presence of neurotoxins (except for veratridine, the rapid action of which does not require preincubation). ${ }^{22} \mathrm{Na}^{+}$flux assays were started by the addition of $0.2 \mathrm{ml}$ of prewarmed incubation medium, consisting of SFM with $10 \mathrm{mM} \mathrm{NaCl}$ replacing $10 \mathrm{~mm}$ of choline chloride, to which were added ${ }^{22} \mathrm{Na}^{+}(1 \mu \mathrm{Ci}$ assay), $5 \mathrm{~mm}$ ouabain, and neurotoxins at the concentrations specified in Results. While veratridine was added to the incubation medium only, other toxins were also present during preincubation to ensure equilibrium binding (Catterall, 1981a). The incubation was at $37^{\circ} \mathrm{C}$ (for times specified in the legends to figures) and was stopped by the addition of $2 \mathrm{ml}$ of SFM at $4^{\circ} \mathrm{C}$ and rapid filtration (Millipore HAWP) under vacuum. The filters were rinsed twice with $2 \mathrm{ml}$ of SFM at $4^{\circ} \mathrm{C}$; total filtration time was less than $15 \mathrm{sec}$. The residual radioactivity on filters was measured by gamma counting (Packard Autogamma 500). It should be pointed out that the absolute values of ${ }^{22} \mathrm{Na}^{+}$influx into brain cells in suspension, measured in filtration assays, were lower than the values obtained on substrate attached cells. This is apparently due to partial loss of intracellular ${ }^{22} \mathrm{Na}^{+}$during the filtration under vacuum, leading to a systematic underestimation of ${ }^{22} \mathrm{Na}^{+}$uptake. Nevertheless, within an experimental series, the relative values of $\mathrm{Na}^{+}$influx were fairly well maintained since estimations of $K_{0.5}$ were reproducible.

\section{Measurements of ${ }^{22} \mathrm{Na}^{+}$influx in cultured cells}

Sodium influx through the voltage-sensitive sodium channcls was measured in substrate-attached cultures of fetal brain neurons essentially as described by Catterall et al. (1981). Cell cultures were washed with SFM and preincubated with neurotoxins (except for veratridine) to ensure equilibrium binding. For preincubation a modified SFM was used, with $140 \mathrm{~mm} \mathrm{KCl}$ replacing choline chloride, to prevent the loss of intracellular $\mathrm{K}^{+}$. After $20 \mathrm{~min}$ at $37^{\circ} \mathrm{C}$ the preincubation medium was replaced by prewarmed incubation medium $(0.5 \mathrm{ml} /$ well or $1 \mathrm{ml} /$ culture plate). The composition of incubation medium was as for brain cells in suspension except that ${ }^{22} \mathrm{Na}^{+}$was at $0.25-1 \mu \mathrm{Ci} / \mathrm{ml}$. Toxins other than veratridine were included both in preincubation and incubation media. At the end of the incubation time, the medium was aspirated and cells were rinsed three times with $1 \mathrm{ml}$ of SFM at $4^{\circ} \mathrm{C}$. The total time required for rinses was less than $15 \mathrm{sec}$. Cells were dissolved in $0.1 \mathrm{M} \mathrm{NaOH}$, and the residual radioactivity was measured. The reproducibility of the flux assays on substrate-attached neuronal cultures was quite remarkable.

\section{Results}

\section{Sodium influx studies on brain cells developing in vivo}

Veratridine - with or without $\alpha$-ScTx - stimulates sodium influx into dissociated fetal brain cells (Fig. 1 $a$ ). The rate of influx remains linear for less than $30 \mathrm{sec}$, and a plateau is attained at about $5 \mathrm{~min}$. In the presence of the two toxins, the initial rate of ${ }^{22} \mathrm{Na}^{+}$uptake is higher than in the presence of veratridine alone. The maximal uptake level attained is also somewhat higher. The effect of both toxins is blocked by $1 \mu \mathrm{M}$ TTX (not shown).

The neurotoxin-sensitive sodium influx was examined in fetal brain cells at 11-19 d of gestation. Flux assays were not done beyond fetal day 19 because of the low ratio of viable cells recovered after dissociation. The results are shown in Figure 2 and in Table 1. No toxin-sensitive ${ }^{22} \mathrm{Na}^{+}$influx was detected before the 12 th $\mathrm{d}$ of gestation. The maximal specific ${ }^{22} \mathrm{Na}^{+}$uptake per cell sample increases with gestational age (Fig. 2) and so does the initial rate of ${ }^{22} \mathrm{Na}^{+}$uptake (Fig. $1 b$ ).

The $K_{0.5}$ values, i.e., the toxin concentrations required to produce a half-maximal effect on ${ }^{22} \mathrm{Na}^{+}$influx, were determined for veratridine, $\alpha$-ScTx, and TTX on fetal brain cells at $E_{15}$ and at $E_{18}$. The results are summarized in Table 1, and representative dose-response curves are shown in Figure 3 . The apparent affinities of the neurotoxins studied are about equal at $E_{15}$ and $\mathrm{E}_{18}$, indicating a similarity in the pharmacological properties of sodium channels at these stages of development. As shown in Figure $3 a$, preincubation of brain cells with $\alpha$-ScTx lowers the $K_{0.5}$ of vcratridine from 7 to $0.5 \mu \mathrm{M}$ (increase in affinity). This effect is consistent with a positive cooperativity in channel activation between toxins acting at site 2 and toxins acting at site 3 of the $\mathrm{Na}^{+}$channel (Catterall, 1977; Tamkun and Catterall, 1981). The $K_{0.5}$ of $\alpha$-ScTx $(0.5-0.6 \mathrm{nM})$, derived from doseresponse curves as shown in Figure $3 b$, is very similar to the dissociation constant of ${ }^{125} \mathrm{I}-\alpha-\mathrm{ScT}$ x binding to fetal brain cells $\left(K_{D} \approx 0.2-0.5 \mathrm{~nm}\right.$; Berwald-Netter et al., 1981). Also, in agree- 


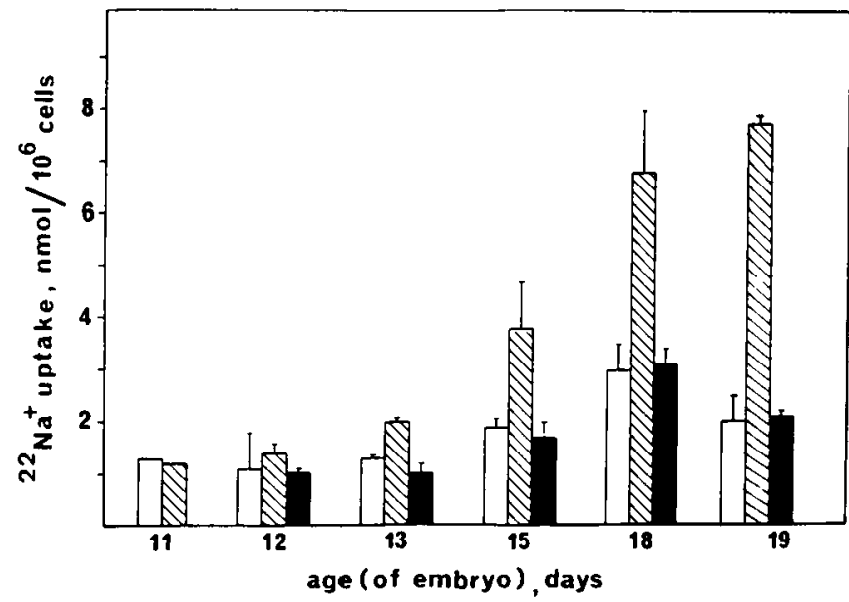

Figure 2. Evolution of neurotoxin-sensitive ${ }^{22} \mathrm{Na}^{+}$uptake in fetal brain cells. Cells were dissociated from fetal brains at the indicated ages and ${ }^{22} \mathrm{Na}^{+}$uptake determined after $5 \mathrm{~min}$ incubation without any toxin (blank bars), in the presence of $100 \mu \mathrm{M}$ veratridine plus $0.1 \mu \mathrm{M} \alpha-\mathrm{ScTx}$ (striped bars), or in the presence of $100 \mu \mathrm{M}$ veratridine, $0.1 \mu \mathrm{M} \alpha-\mathrm{ScTx}$, and $1 \mu \mathrm{M}$ TTX (solid bars).

ment with previous observations on rat brain synaptosomes (Tamkun and Catterall, 1981), at resting membrane potential the $K_{0.5}$ of $\alpha-\mathrm{ScTx}$ is affected little or not at all by the presence of veratridine (see Table 1).

TTX inhibits the veratridine and $\alpha$-ScTX-dependent increase in ${ }^{22} \mathrm{Na}^{+}$uptake, with a $K_{0.5}$ of $20-60 \mathrm{nM}$. This value is similar to the $K_{D}$ of TTX binding (determined at $37^{\circ} \mathrm{C}$ under flux assay conditions, in ${ }^{3} \mathrm{H}$-saxitoxin binding competition experiments; Beaudoin et al., in press).

\section{Sodium influx in neuronal cell cultures}

In order to examine the pharmacological properties of sodium channels during neuronal maturation in vitro, we have systematically compared the effects of neurotoxins on ${ }^{22} \mathrm{Na}^{+}$influx into neuronal cells at an early ( 2 d) and at a relatively advanced (9$12 \mathrm{~d})$ stage of differentiation in culture. Results presented in Figure 4 show that from the 2 nd $d$ on, both the amplitude and the initial rate $\left(v_{i}\right)$ of the toxin-sensitive $\mathrm{Na}^{+}$influx increased with time in culture. The $v_{i}$ at 2,3 , and $11 \mathrm{~d}$ in vitro were respectively 7,14 , and $88 \mathrm{nmol} \mathrm{Na}^{+} / \mathrm{min} / 10^{6}$ cells.

The relative efficacy of BTX and veratridine in stimulating $\mathrm{Na}^{+}$influx was compared, as shown in Figure $4 c$. In the presence of saturating concentrations of BTX, the $v_{i}$ was $70 \mathrm{nmol} \mathrm{Na}^{+}$
Table 1. Apparent affinities, $K_{0,5}$ of neurotoxin effects on ${ }^{22} \mathrm{Na}^{+}$ uptake

\begin{tabular}{|c|c|c|}
\hline \multirow[b]{2}{*}{ Toxin } & \multicolumn{2}{|l|}{ Fetal age } \\
\hline & $\overline{15 d}$ & $18 \mathrm{~d}$ \\
\hline Veratridine & 3-8 $\mu \mathrm{M}$ & $6-7 \mu \mathrm{M}$ \\
\hline$\alpha-\mathrm{ScTx}$ & Not determined & $0.6 \mathrm{~nm}$ \\
\hline$\alpha-\operatorname{ScTx}(+ \text { veratridine })^{a}$ & $0.4 \mathrm{~nm}$ & $0.5-0.6 \mathrm{nM}$ \\
\hline Tetrodotoxin ${ }^{b}$ & $20-50 \mathrm{~nm}$ & $50-60 \mathrm{nM}$ \\
\hline
\end{tabular}

The data were obtained from dose-response assays in fetal mouse brain cells (see Fig. 3).

a Veratridine concentrations were 10 and $1 \mu \mathrm{M}$, respectively, in assays on $\mathrm{E}_{15}$ and $\mathrm{E}_{18}$ cells.

${ }^{b}$ Inhibition of the effect induced by $0.3 \mathrm{~mm}$ veratridine $+0.1 \mu \mathrm{M} \alpha$-ScTx.

$\min / 10^{6}$ cells. This is about twice as fast as the $v_{i}$ determined in the presence of excess veratridine $\left(40 \mathrm{nmol} \mathrm{Na}+/ \mathrm{min} / 10^{6} \mathrm{cells}\right)$ indicating that, as in other neuronal cell preparations, BTX is a full agonist of $\mathrm{Na}^{+}$channels, whereas veratridine is a partial one (Catterall, 1977; Tamkun and Catterall, 1981).

The initial rate of $\mathrm{Na}^{+}$uptake depends on the activating-toxin concentration and a half-maximal effect was obtained at $0.4 \mu \mathrm{M}$ BTX and at $12 \mu \mathrm{M}$ veratridine (Fig. 5). In the presence of $\alpha$-ScTx $(0.2 \mu \mathrm{M})$, the apparent affinities of BTX and veratridine are increased, and the new $K_{0.5}$ values are respectively $10 \mathrm{nM}$ and $1.2 \mu \mathrm{M}$ (Fig. 5, $a, b$ ). The amplitude of maximal $\mathrm{Na}^{+}$influx was increased by the addition of $\alpha$-ScTx to cells incubated with veratridine but not to cells incubated with BTX, confirming that BTX, but not veratridine, is a full agonist. Conversely, the addition of veratridine provokes a large increase in the maximal level of $\alpha$-ScTx-induced ${ }^{22} \mathrm{Na}^{+}$uptake but only a small increase in $\alpha$-ScTx apparent affinity: $K_{0.5}=0.3 \mathrm{nM}$ in the presence of veratridine as compared with $K_{0.5}=0.8 \mathrm{~nm}$ without it (Fig. $6 a$ ). When preincubation with $\alpha$-ScTx was done under depolarizing conditions, at a high $\mathrm{K}^{+}$concentration (data not shown), the apparent affinity was lower $\left(K_{0.5}=2 \mathrm{nM}\right)$. This is consistent with the known dependence of $\alpha-\mathrm{ScTx}$ binding on membrane potential: The more the membrane is depolarized, the lower the affinity (Catterall, 1981a; Jover et al., 1980b). Stimulation of ${ }^{22} \mathrm{Na}^{+}$uptake by veratridine or BTX (with or without $\alpha-\mathrm{ScTx}$ ) is completely abolished by TTX or by saxitoxin. The respective apparent affinities of these two channel blockers $\left(K_{0.5}\right.$ of 10 and $2 \mathrm{nM}$; Fig. 6b) agree with their $K_{D}$ values, when determined under identical conditions of incubation (Beaudoin et al., in press).
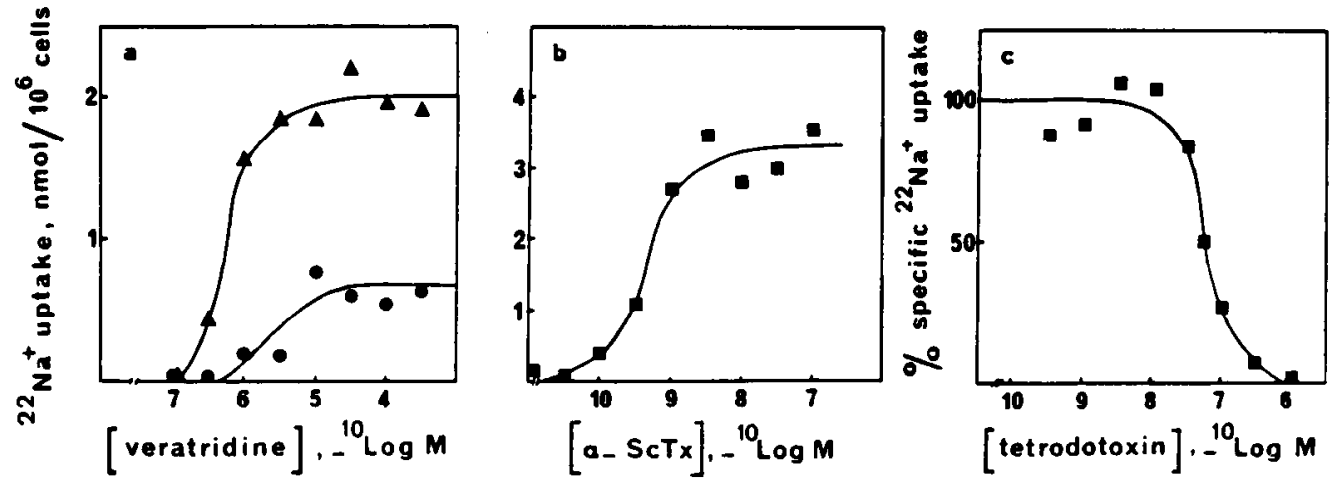

Figure 3. Concentration-effect curves of neurotoxin induced ${ }^{22} \mathrm{Na}^{+}$uptake in fetal brain cell suspensions. Cells were dissociated from fetal mouse brains at $15 \mathrm{~d}(a)$ or $18 \mathrm{~d}(b, c)$ of gestation. $a$, Response to veratridine in the absence $(0)$ or presence $(\Delta)$ of $0.1 \mu \mathrm{M} \alpha$-ScTx. $b$, Effect of $\alpha$-ScTx in the presence of $1 \mu \mathrm{M}$ veratridine. $c$, Effect of TTX in the presence of $300 \mu \mathrm{M}$ veratridine plus $0.1 \mu \mathrm{M} \alpha$-ScTx. Nonspecific uptake, i.e., uptake observed in the absence of the toxin studied, was subtracted. For TTX, results are expressed as the percentage of the maximal specific (toxininduced) uptake. 

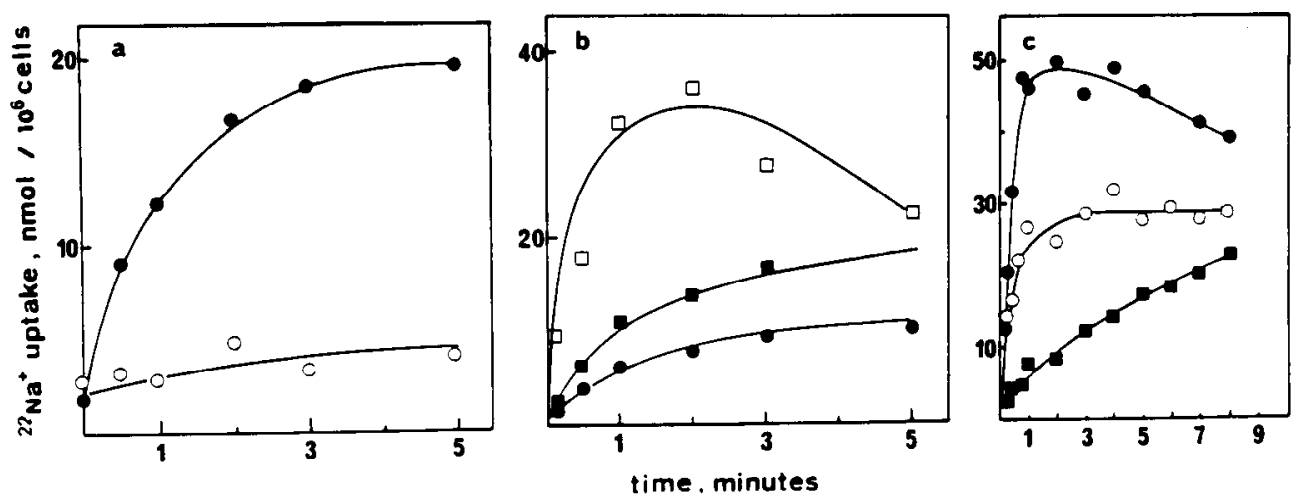

Figure 4. Time course of the neurotoxin-sensitive ${ }^{22} \mathrm{Na}^{+}$uptake into neuronal cell cultures. ${ }^{22} \mathrm{Na}^{+}$uptake was measured as described in Methods, in the presence or absence of neurotoxins. $a$, Response to $100 \mu \mathrm{M}$ veratridine plus $0.1 \mu \mathrm{M} \alpha$-ScTx (๑) at $2 \mathrm{~d}$ in vitro; nonspecific uptake (without toxins) is also shown (O). b. Comparison of neurotoxin-stimulated ${ }^{22} \mathrm{Na}^{+}$uptake kinetics in cultures at $2(0), 3(\square)$, and 11 ( $\square$ ) $\mathrm{d}$ in vitro. The toxins werc as in $a$, and corresponding nonspecific uptake was subtracted. $c$, Kinetics of response to $2 \mu \mathrm{M} \mathrm{BTX} \mathrm{( \bullet )} \mathrm{or} 200 \mu \mathrm{M}$ veratridinc (O), as comparcd with nonspecific ${ }^{22} \mathrm{Na}^{+}$uptake without toxins $(\square)$ in $12 \mathrm{~d}$ neuronal cell cultures.

Comparative ${ }^{22} \mathrm{Na}^{+}$flux assays made on neurons in culture at $2 \mathrm{~d}$ or 9-12 $\mathrm{d}$ in vitro (Table 2) revealed no difference in the apparent affinities of $\alpha$-ScTx, TTX, or saxitoxin. The values of $K_{0.5}$ in vitro agree with homologous $K_{0.5}$ estimations in assays on brain cell suspensions (Table 1) and with the dissociation constants for $\alpha$-ScTx $\left(K_{D}=0.2-0.5 \mathrm{nM}\right)$ and saxitoxin $\left(K_{D}=5\right.$ $\mathrm{nM}$ ) determined in independent toxin binding experiments on fetal brain neurons in culture (Berwald-Netter et al., 1981; and Beaudoin et al., in press). The only notable change observed during neuronal maturation in vitro was an increase in the apparent affinity for BTX and veratridine, which, in cells cultured for $2 \mathrm{~d}$, is an order of magnitude lower (higher $K_{0.5}$ ) than in cells cultured for 9-12 d (Table 2). However, when the flux was measured in the presence of $\alpha-\mathrm{ScTx}$, which reduces the $K_{0.5}$ for both BTX and veratridine, the respective values are virtually identical in cultures of both ages (Table 2).

\section{Discussion}

In the present study, we establish that a neurotoxin-sensitive sodium influx is detectable in fetal mouse brain cells at a very early stage of ontogenetic development. The time of emergence of this function, on the 12 th $\mathrm{d}$ of gestation, coincides with the time of appearance of specific binding sites for $\alpha-\mathrm{ScTx}$ and saxitoxin. To our knowledge, this is the earliest detection of functional $\mathrm{Na}^{+}$channels in mammalian brain. Veratridine- and TTX-sensitive $\mathrm{Na}^{+}$influx has been previously reported for chick embryonic brain cells derived from $8 \mathrm{~d}$ telencephalon and cultured for $2 \mathrm{~d}$ in vitro (Pado et al., 1980). These cells, however, would be analogous to $17 \mathrm{~d}$ fetal mouse telencephalic cells, based on the times of neural tube formation and of mitotic arrest of specific neuronal subpopulations, which in the mouse lag by about $7 \mathrm{~d}$ as compared with the chick.
In the developing mouse brain, the initial appearance of neurons-identified as postmitotic cells either by permanent ${ }^{3} \mathrm{H}$ thymidine nuclear labeling (Sidman, 1970) or cell surface labeling with tetanus toxin (Koulakoff et al., 1982, 1983)-occurs between the 9 th and 10 th $\mathrm{d}$ of gestation. Thus, functional $\mathrm{Na}^{+}$ channels are detectable about $2 \mathrm{~d}$ after the "birth" of the earliest neuronal cells. This delay may either be ascribed to the limits of sensitivity of the $\mathrm{Na}^{+}$channel assays or correspond to a biologically meaningful interval, required for some process of neuronal maturation, that takes place between the terminal mitosis and the initial expression of $\mathrm{Na}^{+}$channels. We tend to favor the second hypothesis, mainly because of the striking synchrony in the ontogenetic emergence of three distinct $\mathrm{Na}^{+}$-channel-related parameters, detected by three independent assays: i.e., specific binding of ${ }^{125} \mathrm{I}-\alpha-\mathrm{ScT}$, specific binding of ${ }^{3} \mathrm{H}$-saxitoxin, ${ }^{22} \mathrm{Na}^{+}$ influx stimulated by alkaloid toxins and blocked by TTX or saxitoxin. Moreover, studies on neuronal development in amphibia show that in Rohon-Beard neurons, $\mathrm{Na}^{+}$-dependent excitability appears a substantial time after their final DNA synthesis (Baccaglini and Spitzer, 1977). One cannot, however, entirely rule out that a very low density of $\mathrm{Na}^{+}$channels exists even earlier but is neither detectable by toxin binding or ionflux assays nor sustains the generation of $\mathrm{Na}^{+}$-dependent action potentials.

Another question addressed by our study is that of the pharmacological properties of $\mathrm{Na}^{+}$channels during neuronal maturation in vivo or in culture. Because of the relatively low level of specific ${ }^{22} \mathrm{Na}^{+}$influx, in vivo stages earlier than $\mathrm{E}_{13}$, were not investigated in detail. Nevertheless, at $15 \mathrm{~d}$ of gestation, active neurogenesis still takes place in most areas of the mouse brain, while at $18 \mathrm{~d}$ most brain neurons are already postmitotic, cerebellar neurons excepted (Koulakoff et al., 1982, and references
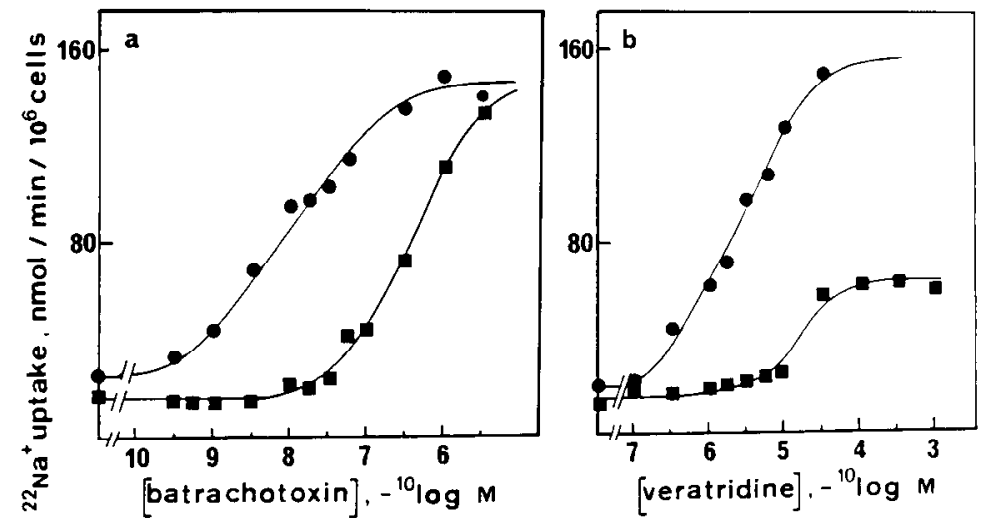

Figure 5. Dose-response to sodium channel agonists: effect on ${ }^{22} \mathrm{Na}^{+}$uptake into neuronal ccll culturcs. Rcsponse to BTX $(a)$ or veratridine $(b)$ measured in the absence $(\square)$ or presence ( $)$ of $0.2 \mu \mathrm{M}$ of $\alpha-\mathrm{ScTx}$. The incubation time was $15 \mathrm{sec}$ and the cultures were at 12-13 d in vitro. 
Figure 6. Modification of ${ }^{22} \mathrm{Na}^{+}$uptake into neuronal cell cultures by $\alpha$ ScTx, TTX, or saxitoxin. $a$, Concentration-effect curves for $\alpha$-ScTx measured in the absence (D) or presence (ब) of $1 \mu \mathrm{M}$ veratridine. $b$, Inhibition of veratridine $(10 \mu \mathrm{M})$ stimulated ${ }^{22} \mathrm{Na}^{+}$ uptake by TTX $(\square)$ or saxitoxin $(\theta)$. Dose-response assays were done on cultures at $12 \mathrm{~d}$ in vitro. The results are expressed as a percentage of $\max$ imal specific effect.
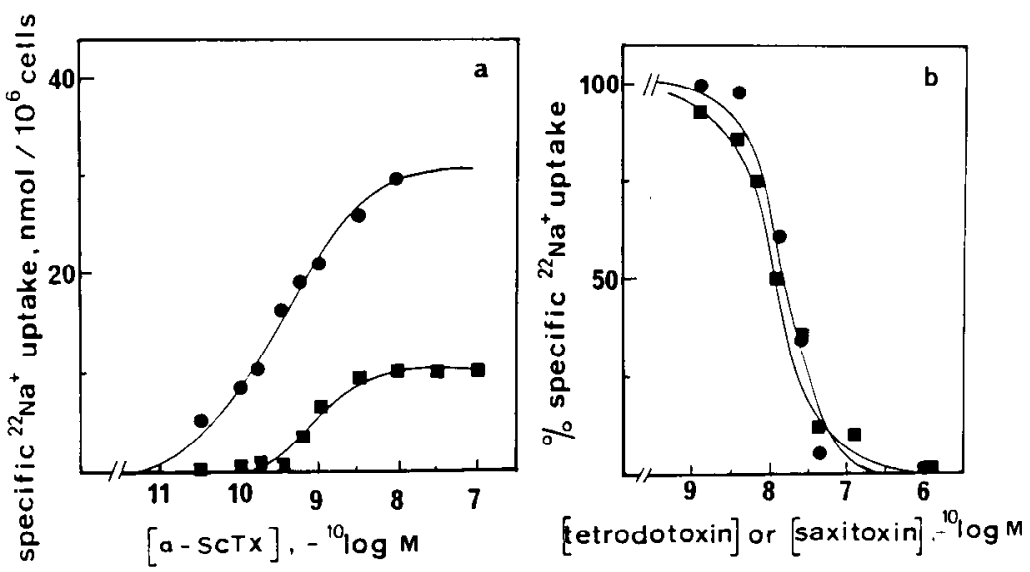

therein). Comparison of response to neurotoxins in $E_{15}$ and $E_{18}$ brain cell suspensions revealed no significant differences in the apparent affinities for veratridine, $\alpha-\mathrm{ScTx}$, or TTX. However, the known developmental asynchrony of neuronal subpopulations in the brain renders the interpretation of such data tenuous, since differences in the properties of a minority of cells may be easily masked by similarities in cell majority. On the other hand, neuronal maturation in culture is relatively synchronous, and the use of antimitotic agents to block cell multiplication, in particular of glia, allows the investigation of a constant population of cells. The period of neuropil formation-consisting of neurite sprouting, elongation, and arborization - occurs mostly during the first week of culture, the neuritic network becoming relatively stable thereafter, as judged by direct observation by LM and protein assay (although one cannot exclude a prolonged addition of fine neuritic fibers). Thus, cells engaged in active membrane expansion can be compared with cells at more advanced stages of phenotypic maturation.

The initial rate and the maximal level of ${ }^{22} \mathrm{Na}^{+}$uptake into brain cells increase as a function of fetal age or time in culture, as does the abundance of $\alpha-\mathrm{ScT}$ x and saxitoxin receptors during equivalent periods in vivo or in vitro. This time-dependent evolution in ${ }^{22} \mathrm{Na}^{+}$flux rates and toxin binding capacity is undoubtedly related to a developmentally regulated increase in sodium channel density in brain tissue. Both an increase in the percentage of $\mathrm{Na}^{+}$channel-bearing cells and in channel density per cell are likely to contribute to this process, as indicated by our quantitative autoradiographic study of ${ }^{125} \mathrm{I}-\alpha$-ScTx labeling in brain cell suspensions showing a time-dependent increase in the proportion of toxin binding cells as well as in the mean number

Table 2. Apparent affinities, $K_{0.5}$, of neurotoxin effects on cultured neuronal cells

\begin{tabular}{|c|c|c|}
\hline \multirow[b]{2}{*}{ Toxin } & \multicolumn{2}{|l|}{ Time in culture } \\
\hline & $2 \mathrm{~d}$ & $9-12 \mathrm{~d}$ \\
\hline Veratridine & $90 \mu \mathrm{M}(6)$ & $8.6 \mu \mathrm{M}(11)$ \\
\hline Veratridine $(+\alpha-\operatorname{ScTx}, 0.1 \mu \mathrm{M})$ & $2 \mu \mathrm{M}(3)$ & $1.6 \mu \mathrm{M}(4)$ \\
\hline Batrachotoxin & $6 \mu \mathrm{M}(3)$ & $0.3 \mu \mathrm{M}(2)$ \\
\hline Batrachotoxin $(+\alpha-\operatorname{ScTx}, 0.1 \mu \mathrm{M})$ & $6 \mathrm{nM}(2)$ & $5 \mathrm{~nm}(2)$ \\
\hline$\alpha-\operatorname{ScTx}$ & Not determined & $0.5 \mathrm{~nm}(3)$ \\
\hline$\alpha$-ScTx (+veratridine, $10 \mu \mathrm{M}$ ) & $0.35 \mathrm{~nm}(4)$ & $0.3 \mathrm{~nm}(3)$ \\
\hline Tetrodotoxin ${ }^{a}$ & $15 \mathrm{nM}(1)$ & $10 \mathrm{nM}(3)$ \\
\hline Saxitoxin ${ }^{a}$ & 10 nм (1) & 20 пм (2) \\
\hline
\end{tabular}

The data were obtained from dose-response curves (see Figs. 5 and 6 ). The number of experiments is given in parentheses.

${ }^{a}$ Inhibition of $\mathrm{Na}^{+}$influx induced by $10 \mu \mathrm{M}$ veratridine $+0.1 \mu \mathrm{M} \alpha-\mathrm{ScTx}$. of silver grains per cell (Martin-Moutot et al., unpublished observations). However, due to the variability in the absolute values of ${ }^{22} \mathrm{Na}^{+}$influx per cell sample among independent assays (see Methods), a strict comparison of the ion flux data with toxin binding data could not be done on brain cell suspensions.

In contrast, flux assays on cultures of substrate-attached neuronal cells are sufficiently precise and reproducible to permit the calculation of ionic flux per channel by relating the maximal ion flux per cell to toxin binding capacity per cell. The abundance of putative $\mathrm{Na}^{+}$channels has in fact been determined, by saxitoxin and/or $\alpha$-ScTx binding assays, in a series of neuronal cultures set up in parallel to those used in the present report (Beaudoin et al., in press). In cultures used in the experiments shown in Figure $5 b$, for instance, the number of saxitoxin receptors per cell was about 210,800 , and the maximum BTXstimulated ${ }^{22} \mathrm{Na}^{+}$influx was $120 \mathrm{nmol} \mathrm{Na}+/ \mathrm{min} / 10^{6}$ cells. After linear extrapolation of the results obtained at $10 \mathrm{~mm}$ external $\mathrm{Na}^{+}$to the physiological concentration of $145 \mathrm{mM}$, computation of the corresponding $\mathrm{Na}^{+}$transport rate gives the value of $5 \times$ $10^{6} \mathrm{Na}^{+}$ions $/ \mathrm{min} /$ saxitoxin site. This value is not far from the values arrived at, by a similar approach, in the case of mouse neuroblastoma cells, $2.9 \times 10^{6} \mathrm{Na}^{+}$ions $/ \mathrm{min} /$ saxitoxin site (Catterall, 1977), or in rat brain synaptosomes, $1.4 \times 10^{6} \mathrm{Na}^{+}$ ions/min/saxitoxin site (Tamkun and Catterall, 1981).

In keeping with toxin binding experiments-showing constancy in the $K_{D}$ valucs for $\alpha$-ScTx, saxitoxin, and TTX during neuronal maturation in vivo and in vitro (Baumgold et al., 1983; Beaudoin et al., in press; Berwald-Netter et al., 1981)-the apparent affinities of these toxins, measured by ${ }^{22} \mathrm{Na}^{+}$influx, are constant as well. The only change observed in neuronal cultures at $\geq 9 \mathrm{~d}$, as comparcd with cultures at $\leq 2 \mathrm{~d}$, was an increase by about one order of magnitude in the apparent affinity of BTX and veratridine. Alternatively, consistent with the similarity in $K_{0.5}$ values in dissociated brain cell preparations and in cells cultured for $\geq 9 \mathrm{~d}$, one may consider this evolution as a decrease in the affinity for the alkaloid toxins when cells are cultured for a short time, followed by a return to the condition present before the cells were placed in culture. In the presence of $\alpha-\mathrm{ScTx}$, however, the apparent affinities of channel activation by the alkaloid toxins are higher, and equal in young and in older cultures. Indeed, besides enhancing the activation of $\mathrm{Na}^{+}$channels by the liposoluble alkaloid toxins, $\alpha$-scorpion toxins are also known to enhance their binding affinity (Catterall, 1977; Catterall et al., 1981; Tamkun and Catterall, 1981). One possible, if hypothetical, explanation of the change in binding affinity of BTX and veratridine during neuronal maturation would be a modification in membrane composition, possibly of lipids. It may be pertinent to point out that in the older cultures a great majority of $\mathrm{Na}^{+}$channels are localized on neuritic processes (Boudier et al., 1985; Catterall, $1981 \mathrm{~b}$ ), whereas at $2 \mathrm{~d}$ in vitro, 
most of the channels are probably still limited to the cell body membrane.

The fact that $\alpha$-ScTx alone can induce an increase in sodium permeability, both in neuronal cell cultures and in brain cell suspensions, is worth noting. This finding contrasts with the lack of measurable stimulation of $\mathrm{Na}^{+}$influx by $\alpha$-ScTx alone in mouse neuroblastoma cells (Catterall, 1977) but is similar to results on cultured embryonic heart cells (Couraud et al., 1980). As $\alpha$-ScTx has no direct effect on the activation of sodium channels (Catterall, 1980; Couraud et al., 1982), this indicates the existence of a spontaneous activation of part of the sodium channels present in fetal brain neurons developing in vivo or in vitro. Spontaneous electrical activity has indeed been recorded in samples of the brain cell cultures used in the present study (Takeda et al., unpublished results), as well as in young cultures of mouse spinal cord (Jackson et al., 1982; Ransom et al., 1977) and quail neural crest cells (Bader et al., 1983).

In the light of several recent reports describing $\mathrm{Na}^{+}$channels in astrocytic glial cells (reviewed in Berwald-Netter et al., 1985; Gray and Ritchie, 1985), it should be pointed out that (1) the relative abundance of astrocytes, judged by immunocytochemical staining with anti-GFAP antibodies (not shown), was $<1 \%$ in brain cell suspensions and $\approx 5 \%$ in the oldest cultures studied, where, in view of the persistent treatment with antimitotics (see Materials and Methods), their presence may be attributed to astrocytic differentiation of some precursor cells rather than to cell division. (2) Though mouse brain astrocytes in culture do express $\mathrm{Na}^{+}$channels that can be chemically activated, their $\mathrm{Na}^{+}$channel density is quite low compared with that of neurons at $\geq 9 \mathrm{~d}$ in culture. (3) The activation of astrocytic $\mathrm{Na}^{+}$channels by specific neurotoxins requires significantly higher toxin(s) concentration than the activation of neuronal $\mathrm{Na}^{+}$channels, and, under the experimental conditions used, veratridine alone has no effect (Berwald-Netter et al., 1985, and references therein). The contribution of glial cells to the results presented is thus unlikely and, if present, is negligible.

During development of mammalian skeletal muscle in vivo (Sherman and Catterall, 1982) or in culture (Frelin et al., 1984; Sherman et al., 1983) the first sodium channels that appear are relatively insensitive to TTX and to $\alpha-\mathrm{ScTx}$. Later, the muscle cells acquire "adult" channels with high affinity for TTX and $\alpha$-ScTx. Also, both TTX-sensitive and TTX-resistant $\mathrm{Na}^{+}$channels are elicited in mammalian sensory neurons in primary culture but without notable change in their relative abundance during culture (Bossu and Feltz, 1984; Fukuda and Kameyama, 1980). The data in the present study show, in contrast, that sodium channels in mouse brain cells have high affinity for TTX and for $\alpha-\mathrm{ScTx}$ as soon as they are detected. Thus, TTX-insensitive sodium channels do not seem to play a role in the development of mammalian brain neurons.

In conclusion, the results presented indicate that functional $\mathrm{Na}^{+}$channels appear at a very early stage of nervous system organogenesis, coinciding with the time of appearance of saxitoxin and $\alpha$-ScTx binding sites. Their properties, defined by response to neurotoxins, are comparable with the properties of voltage-dependent $\mathrm{Na}^{+}$channels of adult peripheral nerve or brain synaptosomes. The maturation of fetal brain neurons in culture is accompanied by a considerable time-dependent increase in the abundance of functional $\mathrm{Na}^{+}$channels, rendering the in vitro system potentially valuable for the exploration of mechanisms involved in the control of $\mathrm{Na}^{+}$channel expression.

\section{References}

Agnew, W. S. (1984) Voltage-regulated sodium channel molecules. Annu. Rev. Physiol. 46: 517-530.

Baccaglini, P. I., and N. C. Spitzer (1977) Developmental changes in the inward current of the action potential of Rohon-Beard neurons. J. Physiol. (Lond.) 27 1: 93-117.
Bader, C. R., D. Bertrand, E. Dupin, and A. C. Kato (1983) Development of electrical membrane properties in cultured avian neural crest. Nature 305: 808-810.

Baumgold, J., I. Zimmerman, and L. Bambrick (1983) Appearance of ${ }^{3} \mathrm{H}$-saxitoxin binding sites in developing rat brain. Dev. Brain Res. 9: 405-407.

Beaudoin, D., F. Couraud, E. Houzet and Y. Berwald-Netter (in press) Development of voltage-sensitive $\mathrm{Na}^{+}$channels in mouse brain tissue and neurons in vitro. Dev. Neurosci.

Berwald-Netter, Y., A. Koulakoff, L. Nowak, and P. Ascher (1985) Ionic channels in glial cells. In Astrocytes, S. Fedoroff and A. Vernadakis, eds., Academic, New York, in press.

Berwald-Netter, Y., N. Martin-Moutot, A. Koulakoff, and F. Couraud (1981) $\mathrm{Na}^{+}$channel-associated scorpion toxin receptor sites as probes for neuronal evolution in vivo and in vitro. Proc. Natl. Acad. Sci. USA 78: 1245-1249.

Bossu, J. L., and A. Feltz (1984) Patch-clamp study of the tetrodotoxin-resistant sodium current in group $\mathrm{C}$ sensory neurons. Neurosci. Lett. 51: 241-246.

Boudier, J. A., Y. Berwald-Netter, H. D. Dellmann, J. L. Boudier, F Couraud, A. Koulakoff, and P. Cau (1985) Ultrastructural visualization of $\mathrm{Na}^{+}$channel associated ${ }^{125} \mathrm{I}-\alpha$-scorpion toxin binding sites on fetal mouse nerve cells in culture. Dev. Brain Res. 20:137-142.

Catterall, W. A. (1977) Activation of the action potential $\mathrm{Na}^{+}$ionophore by neurotoxins: An allosteric model. J. Biol. Chem. 252: 8669-8676.

Catterall, W. A. (1980) Neurotoxins that act on voltage sensitive sodium channels in excitable membranes. Annu. Rev. Pharmacol. Toxicol. 20: 15-43.

Catterall, W. A. (1981a) Studies of voltage-sensitive sodium channels in cultured cells using ion-flux and ligand-binding methods. In $E x$ citable Cells in Tissue Culture, P. G. Nelson and M. Lieberman, eds. pp. 279-317, Plenum, New York.

Catterall, W. A. (1981b) Localization of sodium channels in cultured neural cells. J. Neurosci. 1: 777-783.

Catterall, W. A. (1984) The molecular basis of neuronal excitability. Science 223: 653-661.

Catterall, W. A., C. S. Morrow, J. W. Daly, and G. B. Brown (1981) Binding of batrachotoxin $\mathrm{A} 20$ - $\alpha$-benzoate to a receptor associated with sodium channels in synaptic nerve ending particles. J. Biol. Chem. 256: 8922-8927.

Couraud, F., H. Rochat, and S. Lissitsky (1980) Binding of scorpion neurotoxins to chick embryonic heart cells in culture and relationship to calcium uptake and membrane potential. Biochemistry 19: 457462.

Couraud, F., E. Jover, J. M. Dubois, and H. Rochat (1982) Two types of scorpion toxin receptor sites, one related to the activation, the other to the inactivation of the action potential sodium channel. Toxicon 20:9-16.

Frelin, C., H. Vijverberg, G. Romey, P. Vigne, and M. Lazdunski (1984) Different functional states of tetrodotoxin sensitive and tetrodotoxin resistant $\mathrm{Na}^{+}$channels occur during the in vitro development of rat skeletal muscle. Pfluegers Arch. 402: 121-128.

Fukuda, J., and M. Kameyama (1980) Tetrodotoxin-sensitive and tetrodotoxin-resistant sodium channels in tissue cultured spinal ganglion neurons from adult mammals. Brain Res. 182: 191-197.

Gray, P. T. A., and J. M. Ritchie (1985) Ion channels in Schwann and glial cells. Trends Neurosci., 411-415.

Jackson, M. B., H. Lecar, D. E. Brenneman, S. Fitzgerald, and P. G. Nelson (1982) Electrical development in spinal cord cell culture. J. Neurosci. 2: 1052-1061.

Jover, E., F. Couraud, and H. Rochat (1980a) Two types of scorpion neurotoxins characterized by their binding to two separate receptor sites on rat brain synaptosomes. Biochem. Biophys. Res. Commun. 95: 1607-1614.

Jover, E., N. Martin-Moutot, F. Couraud, and H. Rochat (1980b) Binding of scorpion toxins to rat brain synaptosomal fraction. Effects of membrane potential, ions and other neurotoxins. Biochemistry 19: 463-467.

Koulakoff, A., B. Bizzini, and Y. Berwald-Netter (1982) A correlation between the appearance and evolution of tetanus toxin binding cells and neurogenesis. Dev. Brain Res. 5: 139-147.

Koulakoff, A., B. Bizzini, and Y. Berwald-Netter (1983) Neuronal acquisition of tetanus toxin binding sites: Relationship with the last mitotic cycle. Dev. Biol. 100: 350-357. 
Lazdunski, M., and J. F. Renaud (1982) The action of cardiotoxins on cardiac plasma membranes. Annu. Rev. Physiol. 44: 463-474.

Miranda, F., C. Kopeyan, H. Rochat, C. Rochat, and S. Lissitzky (1970) Purification of animal neurotoxins. Eur. J. Biochem. 16: 514-523.

Pado, C. H., R. Munson, L. Glaser, and D. I. Gottlieb (1980) Evidence for ionic channcls in cultured chick embryonic CNS cells. Brain Res. 185: 187-191.

Ransom, B. R., E. Neale, M. Henkart, P. N. Bullock, and P. G. Nelson (1977) Mouse spinal cord cells in culture. I. Morphology and intrinsic neuronal electrophysiological properties. J. Neurophysiol. 40: $1132-$ 1150.

Ritchie, J. M., R. B. Rogart, and G. R. Strichartz (1976) A new method for labelling saxitoxin and its binding to non-myelinated fibres of the rabbit vagus, lobster walking leg, and garfish olfactory nerves. J. Physiol. (Lond.) 261: 477-494.

Sherman, S. J., and W. A. Catterall (1982) Biphasic regulation of development of high-affinity saxitoxin receptor by innervation in rat skeletal muscle. J. Gen. Physiol. 80: 753-768.

Sherman, S. J., J. C. Lawrence, D. J. Messner, K. Jacoby, and W. A. Catterall (1983) Tetrodotoxin-sensitive sodium channels in rat muscle cells developing in vitro. J. Biol. Chem. 258: 2488-2495.

Sidman, R. L. (1970) Autoradiographic methods and principles for study of the nervous system with thymidine- ${ }^{3} \mathrm{H}$. In Contemporary Research Methods in Neuroanatomy, W. J. H. Nauta and S. O. E. Ebbeson, eds., pp. 252-274, Springer-Verlag, New York.

Strichartz, G., D. Bar-Sagi, and J. Prives (1983) Differential expression of sodium channel activities during the development of chick skeletal muscle cells in culture. J. Gen. Physiol. 82: 365-384.

Tamkun, M. M., and W. A. Catterall (1981) Ion flux studies of voltage sensitive sodium channels in synaptic nerve ending particles. Mol. Pharmacol. 19: 78-86. 